\title{
Dynamic Patterns of Marine Phytoplankton in Bahrain Sea
}

\author{
Belen T. Lumeran \\ Faculty, Department of Mathematics and Sciences, College of Engineering, AMA International University-Bahrain
}

\begin{abstract}
Marine phytoplankton has a wide range of distribution forming patterns. This study generally aims to determine the multi-directional distribution and dynamic patterns of phytoplankton $15 \mathrm{~km}$ off coast from the docking area of Bahrain Yacht Club in Sitra, Kingdom of Bahrain. Specifically to identify individual species' population in the sampling stations; identify multi-directional distribution and pattern of marine plankton; find out significant differences in the station-to-station distribution of marine plankton; and relate the effect physicochemical parameter on the population of phytoplankton taxa. Results revealed 21 species of phytoplankton consisting of two phyla, Chrysophyta or diatoms with 13 species and Dinoflagellata or dinoflagellates with 8 species. Plankton population based on microscopy count varies from station-to-station. Thalasionema sp. of the diatom taxon dominates Station 1 (northeast), Station 3 (west) and Station 4 (northwest); Pseudo-Nitzschia australis in Station 2 (southwest) and Asteromphalus sp. in Station 5 (north) and C. furca of the dinoflagellates in Station1 (northeast) and 2 (southwest). Statistical analysis using t-test at $\mathrm{p}<.05$ depicted significant differences between Station 1 and 5; and Station 1 and 3 among the diatoms taxa while Station 1, 3 and 4 for dinoflagellates. Recorded physicochemical readings are within the acceptable level, therefore exerts insignificant effect on the population of phytoplankton where $r=-0.38867$. Multi-directional and dynamic patterns are illustrated using radar graph based on species population. The greater number of diatom species indicates good water quality and the physicochemical values which are within the standard level.
\end{abstract}

Keywords: Phytoplankton, Chrysophyta, Dinoflagellata

\section{INTRODUCTION}

The community of phytoplankton is a vital component of both ecological and bio-geochemical function of marine ecosystems. The spatial distribution of phytoplankton is influenced by various factors [1]. The characteristic and temporal variation of phytoplankton is greatly affected by certain environmental variables [2] in their particular habitat. Variation in salinity has a strong influence on the local phytoplankton composition. The local hydrodynamics caused by the action of wind and underwater disturbances influence local migration. Phytoplankton biomass varies with temperature and light intensity. Today, researches show increasing concern on the role of phytoplankton on various levels of the marine ecosystem [3, 4]. Physical and chemical factors may have direct or indirect effects on plankton composition. These factors include temperature, transparency, $\mathrm{pH}$, conductivity, dissolved oxygen (DO), biological oxygen demand (BOD) among others. The relative abundance of phytoplankton is determined by the maximum light intensity utilized for photosynthetic activity [5]. The dynamics of plankton vary with natural cycles and global climate change. In effect, this brought about changes in the behaviour of surface water. The distribution of phytoplankton is correlated to the variability of the physicochemical influences [6]. Migration of phytoplankton is environment-driven characterized by the dynamics of the sea water. Dynamic patterns are varied as influence by the natural cycles and climate change. Seasonal changes trigger phytoplankton dynamics [7]. Phytoplankton dynamics during their productive period partially explains its inter-annual variability. Changes in the annual pattern are also influenced by nutrients [8]. The characteristics of the ocean processes determine the conditioning of the phytoplankton distribution and patterns in a particular marine ecosystem [9]. Hence the dynamism of the marine habitat exerts an effect on the distribution and patterns of phytoplankton. The climatic effects of the ocean provide accurate prediction on the ecosystem responses to the physical environment. Sea temperature as an example of a local environmental condition is associated with changes in phytoplankton abundance [10]. Physicochemical factors determine density, diversity and occurrence of phytoplankton in particular marine water. The effect of seasonal variations in turn determines the distribution, periodicity, quantitative and qualitative composition of the phytoplankton [11,12]. There are potential environmental drivers that affect water masses and seasonal changes contributing to geospatial zonation of phytoplankton. This includes taxonomic composition, abundance and biomass [12]. Phytoplankton having contributed to in the global carbon cycle determines productivity as influenced by global environmental change [13]. The combined effect of thermal breadth as measured by environmental drivers determines the distribution of phytoplankton [14]. Studies on the distribution and dynamic patterns of phytoplankton were conducted in the various marine waters of the world. A study on the spatial and temporal pattern of phytoplankton composition was conducted in Burullus Lagoon in Southern 


\section{International Advanced Research Journal in Science, Engineering and Technology}

Vol. 6, Issue 3, March 2019

Mediterranean Coast of Egypt [15] and in West Harbor, South Caten Mediterranean Sea [16]. The impact of sea water temperature as physical factor on phytoplankton on community was also studied [17]. Other disturbances [18] including salinity and water temperature as indicators [19]. The sprawling marine water in the Kingdom of Bahrain served as the habitat for the micro-community of organisms. The conservation of local marine communities is integrated to the ecological web of marine life. Hence, this community-based field research was conducted to determine the multi-directional distribution and dynamic patterns of phytoplankton. Specifically to (a) assess the species' total population in the identified sampling stations; (b) identify multi-directional distribution and pattern of marine phytoplankton; (c) determine significant differences in the distribution of marine plankton in various directions; (d) monitor in situ physicochemical factors namely: water temperature, salinity, alkalinity and dissolved oxygen; and (e) correlate the effect of the physicochemical values on the total population of phytoplankton in the various sampling stations. The local abundance of marine phytoplankton associated with their multi-directional distribution and dynamic pattern have important role in conservation biology of the marine environment.

\section{RESEARCH METHODOLOLGY}

This particular part is a synopsis of the research methodology in the previous studies conducted by the same author [19].

\section{A. Locale and Date of Conduct}

The study was conducted fifteen (15) kilometers or 9.31 miles off the coast of the north eastern part of Bahrain Yacht Club in Sitra from September and December 2017 and February, March and May 2018 following a way-ward direction. The identified spatial distance is free of human leisure activities such as swimming and jet ski which are often observed in the area. Hence, it is a natural environment for this study.

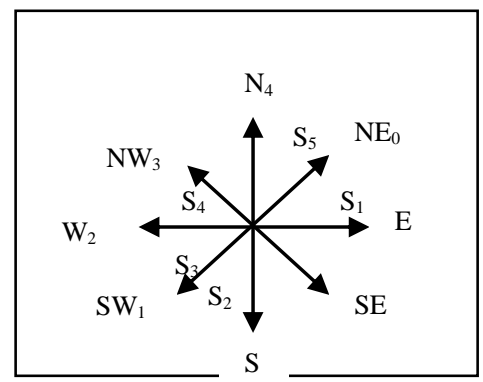

Fig. 1 Sampling patten in established stations

Fig. 1 shows the multi-directional sampling pattern and five (5) identified sampling stations (S) from the north eastern $\left(\mathrm{NE}_{0}\right)$ part of Bahrain Yacht Club in Sitra, moving southwest $\left(\mathrm{SW}_{1}\right)$ direction, going west $\left(\mathrm{W}_{2}\right)$, northwest $\left(\mathrm{NW}_{3}\right)$ direction; and to the northern part $\left(\mathrm{N}_{4}\right)$.

\section{B. Research Design}

An experimental research design is used in this particular study. The experimental variables include the microscopy data of the identified phytoplankton using multi-directional sampling with five (5) established stations (S). Total enumeration of phytoplankton from the various stations determines the total population using settled volume method. The physicochemical parameters as environmental factors such as salinity, alkalinity, surface water temperature, $\mathrm{pH}$, and dissolved oxygen were monitored during the sampling months. These environmental parameters may exert direct or indirect effect on the distribution and dynamic patterns of phytoplankton during the sampling periods.

\section{Statistical Analysis}

Frequency count was used on the occurrence of phytoplankton species in the analysed water samples. Significant difference in the multi-directional distribution and dynamic patterns through station-to-station comparison of the identified plankton species was determined using $\mathrm{T}$-test at $\mathrm{p}<.05$. Pearson $\mathrm{r}$ coefficient of correlation determined the effect of physicochemical factors on the total population of the identified phytoplankton in the various stations.

The following field data gathering procedure was adopted from the Manual of Environmental and Plankton Studies with modifications as used in the previous studies [19].

\section{In Situ Determination of Physicochemical Factors}

Physicochemical determination was done in situ using Marine Science Ecological Kit following the simple field procedure. Physicochemical factors include alkalinity, $\mathrm{pH}$, surface water temperature, dissolved oxygen and salinity. 


\section{International Advanced Research Journal in Science, Engineering and Technology}

Vol. 6, Issue 3, March 2019

\section{E. Collection of Water Samples for Phytoplankton Analysis}

Towed method was used in the collection of water samples in a motorized boat with a constant speed of one knot or 1.852 kilometre per hour $(\mathrm{km} / \mathrm{h})$. Sampling was carried out using plankton net with 60 micron $(\mu \mathrm{m})$ mesh size using a horizontal tow of 315.01 meter long to strain about $30 \mathrm{~m}^{3}$ of sea water.

\section{F. Preservation of Collected Water Samples}

Collected water samples in transparent sampling bottles were field-preserved using $70 \%$ ethyl alcohol. This process prevents desiccation of the planktons. The bottles were then placed in an ice bucket for transport and microscopy analysis in the laboratory.

\section{G. Laboratory Analysis and Taxonomic Classification of Planktons}

Quantitative analysis determined the total abundance and taxonomic composition of the plankton in a unit volume of sea water. Only part of the sample was enumerated from the large number of plankton per sample of about 400 to 500 . Fifty (50) glass slides were used for each station with five (5) drops each of the prepared water sample. Taxonomic identification and classification of plankton from the samples of sea water was conducted using A Guide to the Marine Planktons as primary reference and other taxonomic references.

\section{RESULTS AND DISCUSSION}

Results are presented in the following tables and figures.

\section{A. Species Total Population}

Table 1: Total Population of the Identified Planktons

\begin{tabular}{|c|c|c|c|c|c|c|c|}
\hline \multirow{2}{*}{\multicolumn{2}{|c|}{ Identified Plankton }} & \multicolumn{5}{|c|}{ Total Population } & \multirow[b]{2}{*}{ Total } \\
\hline & & $\begin{array}{l}\text { North East } \\
(\mathbf{N E})\left(\mathbf{S}_{1}\right)\end{array}$ & $\begin{array}{l}\text { South West } \\
(\mathbf{S W})\left(\mathbf{S}_{2}\right)\end{array}$ & $\begin{array}{c}\text { West } \\
(\mathbf{W})\left(\mathbf{S}_{3}\right)\end{array}$ & $\begin{array}{l}\text { North West } \\
(\mathrm{NW})\left(\mathrm{S}_{4}\right)\end{array}$ & $\begin{array}{l}\text { North } \\
(\mathbf{N})\left(\mathbf{S}_{5}\right)\end{array}$ & \\
\hline \multicolumn{8}{|c|}{$\begin{array}{l}\text { I. Phylum Chrysophyta } \\
\text { (Diatoms) }\end{array}$} \\
\hline (1) & Coscinodiscus sp. & 4 & - & 12 & 8 & - & 24 \\
\hline (2) & Asteromphalus sp. & 12 & - & 22 & - & 64 & 98 \\
\hline (3) & Navicula sp. & 8 & 8 & - & 12 & - & 28 \\
\hline (4) & Rhizosolenia sp. & 40 & 4 & - & - & - & 44 \\
\hline $\begin{array}{l}\text { (5) } \\
\text { punct }\end{array}$ & $\begin{array}{l}\text { Thalassiosira } \\
\text { ra }\end{array}$ & 12 & 8 & 16 & 8 & - & 44 \\
\hline$(6)$ & Prosboscia alata & - & - & 20 & - & 8 & 28 \\
\hline $\begin{array}{l}(7) \\
\text { ausra }\end{array}$ & Pseudo-Nitzschia & 4 & 52 & 36 & - & 32 & 124 \\
\hline$(8)$ & Biddulphia mobiliensis & 4 & - & 8 & 4 & 28 & 44 \\
\hline$(9)$ & Ditylium sp. & - & - & - & 20 & - & 20 \\
\hline$(10)$ & Thalasionema sp. & 48 & 16 & 60 & 24 & 40 & 188 \\
\hline (11) & Thalasiosira sp. & 8 & 8 & 16 & 8 & 44 & 84 \\
\hline (12) & Stephanopyxis sp. & 4 & 28 & 8 & 20 & 8 & 64 \\
\hline \multirow[t]{2}{*}{ (13) } & Lauderia annulata & 12 & - & - & 4 & - & 4 \\
\hline & Subtotal & 140 & 124 & 198 & 108 & 224 & 786 \\
\hline \multicolumn{8}{|c|}{$\begin{array}{l}\text { II. Phylum Dinoflagellata } \\
\text { (Dinoflagellates) }\end{array}$} \\
\hline (1) & Ceratium fusus & - & 20 & 32 & 20 & - & 72 \\
\hline (2) & Ceratium furca & 16 & 44 & 16 & - & - & 76 \\
\hline (3) & Ceratium tripos & 4 & - & - & - & 4 & 8 \\
\hline (4) & Prorocentrum micans & 16 & 32 & - & 32 & 92 & 172 \\
\hline$(5)$ & Pololampas palmipes & 4 & 8 & 16 & 16 & 24 & 68 \\
\hline (6) & Dinophysis sp. & - & - & - & 28 & - & 28 \\
\hline (7) & Peridinium sp. & 16 & 8 & - & 24 & - & 48 \\
\hline$(8)$ & Protoperidinium sp. & 4 & - & - & 4 & - & 8 \\
\hline & Subtotal & 60 & 112 & 64 & 124 & 120 & 480 \\
\hline & Total & 200 & 236 & 262 & 232 & 344 & 1,266 \\
\hline
\end{tabular}




\section{International Advanced Research Journal in Science, Engineering and Technology}

Vol. 6, Issue 3, March 2019

Table 1 presents the total population of the identified marine planktons from the five (5) sampling stations on November and December, 2017 and February, March and May 2018. Results show a total of 21 species, 13 species in Phylum Chrysophyta or Diatoms and 8 species that belong to Phylum Dinoflagellata or Dinoflagellates for a total species of 1,266. Diatoms comprised the most species. Of the diatoms group, Thalasionema sp. incurred the highest microscopy count of 48 in Station 1 (north east) while Ceratium furca, Prorocentrum micans and Peridinium sp. of the dinoflagellates group with 16 each total microscopy count. Station 2 in the south west revealed that Pseudo-Nitzschia australis of the diatoms group had the most microscopic count of 52 while dinoflagellate Ceratium furca had 44 total counts. In the west of Station 3, Thalasionema sp. had the highest count of 60 and Ceratium fusus of the dinoflagellate taxon with 32. Moving northwest of Station 4, Thalasionema sp. had the highest count of 24 while the Prorocentrum micans of the dinoflagellate taxon had 32. Samples from Station 5 showed that Asteromphalus sp. had 64 however Prorocentrum micans of the dinoflagellate taxon revealed much higher microscopy count of 92. It can be observed on the variations in the total microscopy count that determine the total population of both phytoplankton phyla. Results show that seasonal variations determine the distribution, periodicity, quantitative and qualitative composition of the phytoplankton $[12,13]$.

B. Multi-directional Distribution and Dynamic Patterns of the Identified Phytoplankton

The following radar graphs present the multi-directional distribution and pattern of phytoplankton taxa.

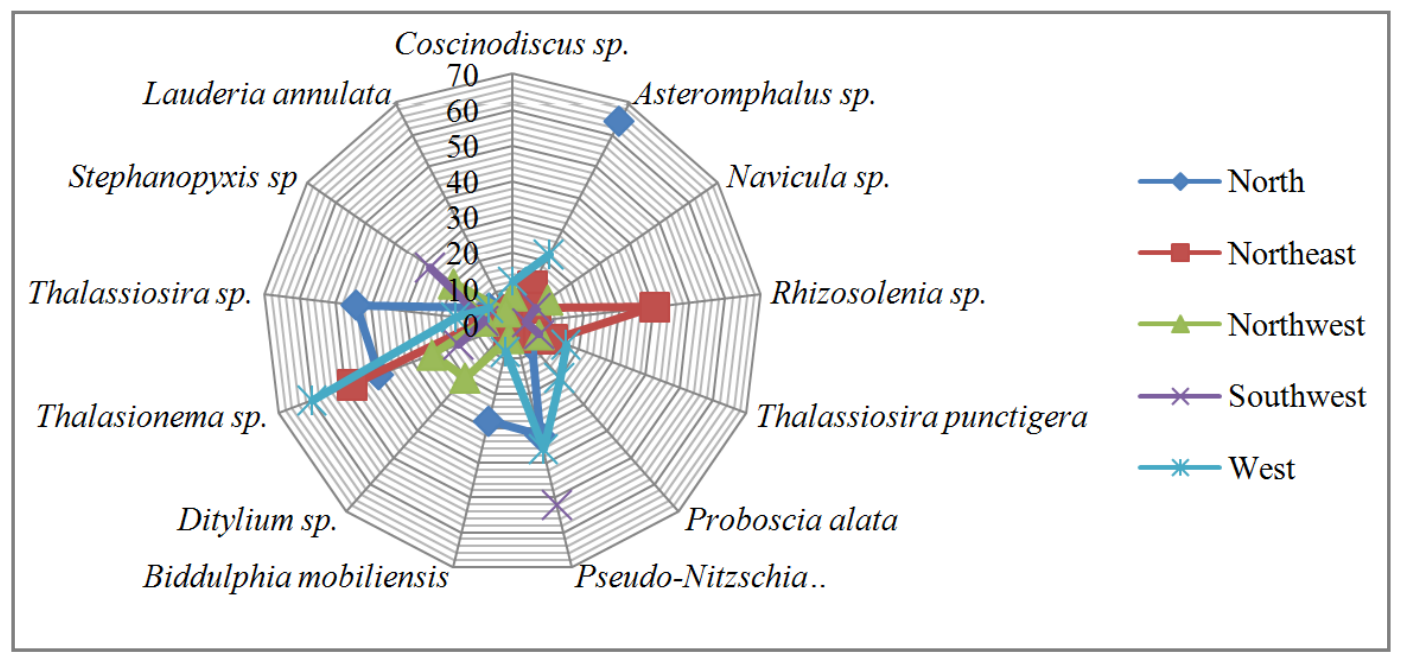

Fig. 2 Multi-directional distribution and dynamic patterns of the identified species of Phylum Chrysophyta (Diatoms)

Fig. 2 generally shows that the population of diatoms is distributed in various directions. Thalasionema sp. has wide range of distribution sampled from station-to-station with a higher population in Station 3 (West). The pattern of distribution is represented by species population as influenced by the characteristics of environmental events [10].

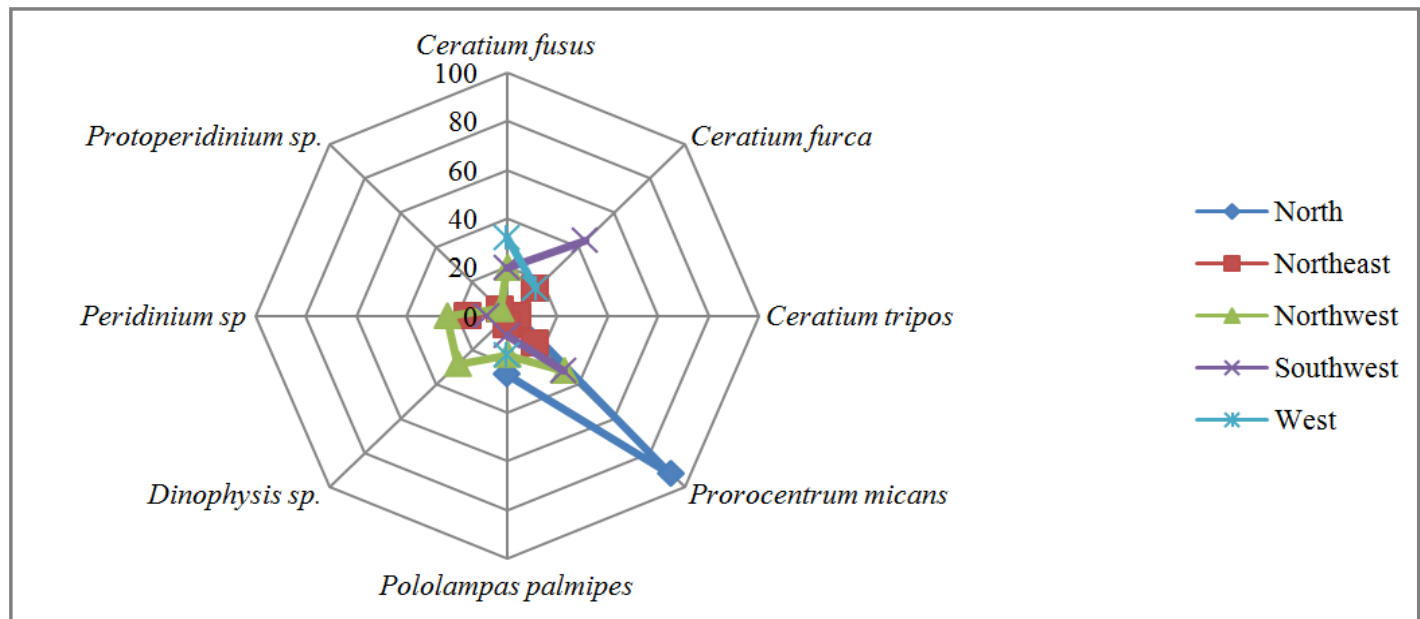

Fig. 3 Multi-directional distribution and dynamic patterns of the identified species of Phylum Dinoflagellata (Dinoflagellates) 


\section{International Advanced Research Journal in Science, Engineering and Technology}

Vol. 6, Issue 3, March 2019

Fig. 3 also shows the multi-directional distribution and pattern of the dinoflagellate taxa but not as dynamic as the diatoms. Prorocentrum micans is found mostly in the north (Station 5); northwest (Station 4), southwest (Station 2) and northeast (Station 1). Multi-directional distribution and pattern of the identified species of plankton are more distinct among the diatoms considering the greater number of population compared to dinoflagellates.

\section{Significant Differences in the Distribution of Marine Plankton in Various Direction}

Comparing station- to- station mean population of individual species using T-test at.05 level of significance showed that there is a significant difference in the multi-directional distribution and pattern in the north east (Station 1) and north (Station 5) parts with a t-value of 0.58738 and $p$-value of 0.046548 , therefore significant at $p<.05$; between the north (Station 5) and in the west (Station 3) with t-value of 1.09375 and $\mathrm{p}$-value of .146264, hence significant at $\mathrm{p}<.05$.

Table 2: Result of T-Test on Station-To-Station Mean Comparison among Individual Species of Phylum Chrysophyta (Diatoms)

\begin{tabular}{|l|c|c|c|}
\hline Phylum Chrysophyta (Diatoms) & t-value & p-value & Conclusion \\
\hline Station 1 (NE) and Station 5 (N) & -1.80209 & .046548 & Significant \\
\hline Station 1 (NE) and Station 4 (NW) & 0.58738 & .282574 & Not Significant \\
\hline Station 1 (NE) and Station 3 (W) & -2.30307 & .025111 & Significant \\
\hline Station 1 (NE) and Station 2 (SW) & 1.43621 & .088281 & Not Significant \\
\hline Station 2 (SW) and Station 3 (W) & -0.50543 & .310561 & Not Significant \\
\hline Station 2 (SW) and Station 5 (N) & -1.43621 & .088248 & Not Significant \\
\hline Station 5 (N) and Station 2 (SW) & 0.47511 & .321618 & Not Significant \\
\hline Station 5 (N) and Station 3 (W) & 1.09375 & .146264 & Not Significant \\
\hline Station 2 (SW) and Station 4 (NW) & 0.09038 & .190688 & Not Significant \\
\hline \multicolumn{2}{|c|}{ *Significant @ p $<.05$} & &
\end{tabular}

Comparing station- to- station mean population of individual species of Phylum Chrysophyta (Diatoms) in Table 2 using T-test at.05 level of significance showed that there is a significant difference in the multi-directional distribution and pattern in Station $1(\mathrm{NE})$ and Station $5(\mathrm{~N})$ with a t-value of -1.80209 and p-value of 0.046548 , therefore significant at $\mathrm{p}<.05$; and between Station 1(NE) and Station $3(\mathrm{~W})$ with t-value of -2.30307 and $\mathrm{p}$-value of .02511, however insignificant in most stations.

Table 3: Result OF T-Test on Station-To-Station Mean Comparison among Individual Species OF Phylum Dinoflagellata (Dinoflagellates)

\begin{tabular}{|c|c|c|c|}
\hline Phylum Dinoflagellata (Dinoflagellates) & t-value & p-value & Conclusion \\
\hline Station $1(\mathrm{NE})$ and Station $2(\mathrm{SW})$ & -1.7777 & .054646 & Not Significant \\
\hline Station $1(\mathrm{NE})$ and Station $3(\mathrm{~W})$ & -2.15652 & .033978 & Significant \\
\hline Station $1(\mathrm{NE})$ and Station $4(\mathrm{NW})$ & -2.19363 & .026505 & Significant \\
\hline Station $1(\mathrm{NE})$ and Station $5(\mathrm{~N})$ & -1.67855 & .068568 & Not Significant \\
\hline Station $2(\mathrm{SW})$ and Station $3(\mathrm{~W})$ & -0.10551 & .459706 & Not Significant \\
\hline Station $2(\mathrm{SW})$ and Station $4(\mathrm{NW})$ & 0.22379 & .41396 & Not Significant \\
\hline Station $2(\mathrm{SW})$ and Station $5(\mathrm{~N})$ & -0.81587 & .222873 & Not Significant \\
\hline Station $3(\mathrm{~W})$ and Station $4(\mathrm{NW})$ & 0.09682 & .462798 & Not Significant \\
\hline Station $3(\mathrm{~W})$ and Station $5(\mathrm{~N})$ & -0.68723 & .264854 & Not Significant \\
\hline
\end{tabular}

Statistically as shown in Table 3, there is a significant difference in the multi-directional distribution and pattern in the mean population of individual dinoflagellate taxa in the northeast (Station 1) and the west (Station 3). The t-value of 2.15652 and the p-value of .033978 depicted significant difference at $p<.05$. Similarly moving eastward in the north side of Station 1 and westward in the north of Station 4 also depicted significant differences with a t-value of -2.19363 and a p-value of .026505. However insignificant differences in most sampled stations.

Results of statistical analysis imply that the species' population of a given taxon determines the multi-directional distribution and pattern of species in a particular area. Considering that planktons are floaters, dynamic patterns are varied as influence by natural cycles and climate change including seasonal changes [7] and nutrients [8]. 


\section{International Advanced Research Journal in Science, Engineering and Technology}

Vol. 6, Issue 3, March 2019

\section{Results of In Situ Monitoring of Physicochemical Parameters}

Table 4: Summary of Physicochemical Factors

\begin{tabular}{|l|c|}
\hline \multicolumn{1}{|c|}{ Physicochemical Factors } & Reading Ranges \\
\hline Surface water temperature & $32^{0} \mathrm{C}-37^{0} \mathrm{C}$ \\
\hline $\mathrm{pH}$ & $8.0-8.0$ \\
\hline Salinity & $40.0^{0} / 000-40.7^{0} / 000$ \\
\hline Alkalinity & $127.6 \mathrm{mgl}^{-1}-132.1 \mathrm{mgl}^{-1}$ \\
\hline Dissolved Oxygen (DO) & $4.2 \mathrm{mgl}^{-1}-5.4 \mathrm{mgl}^{-1}$ \\
\hline
\end{tabular}

Table 4 shows the summary results of the physicochemical factors monitoring showing the reading ranges in the study site using the marine water ecological kit. The surface water temperature depicted a lowest reading of $32^{\circ} \mathrm{C}$ and highest reading of $37^{\circ} \mathrm{C}$ averaging to $34.5^{\circ} \mathrm{C}$ with a $\mathrm{pH}$ of 8.0 . Salinity ranges from $40 . \%^{\circ} \% 00$ to $40.7^{0} \%$ with an average of $40.4 \%$. Alkalinity is the water buffering capacity with recorded values $127.6 \mathrm{mgl}^{-1}$ to $132.1 \mathrm{mgl}^{-1}$ with an average of $129.85 \mathrm{mgl}^{-1}$ and $4.2 \mathrm{mgl}^{-1}$ to $5.4 \mathrm{mgl}^{-1}$ for dissolved oxygen (DO) with an average of $4.8 \mathrm{mgl}^{-1}$. Result revealed that the values are within the acceptable limit with reference to the standard as indicated in marine water ecological kit used in situ during the conduct of the study.

\section{E. Effect of the Physicochemical Factors on the Total Population of the Identified Phytoplankton}

Table 5: Result of Pearson r Coefficient of Correlation

\begin{tabular}{|l|c|c|c|c|}
\hline \multicolumn{1}{|c|}{ Variables } & Sum & Mean & SS & r \\
\hline Physicochemical factors & 217.45 & 43.49 & 10311.98 & -0.3867 \\
\hline Total phytoplankton & 1274 & 254.80 & 11884.80 & \\
\hline
\end{tabular}

Statistical analysis using Pearson $r$ coefficient of correlation in Table 5 showed a negative correlation $(r=-0.3867)$. Result implies that the physicochemical factors have no influence on the distribution and patterns of the identified planktons considering that the mean values are within the acceptable level. Therefore, the surface water temperature, $\mathrm{pH}$, salinity, alkalinity and dissolved oxygen (DO) do not relate to the aggregation of species population of phytoplankton in various directions during the conduct of the study. However, various literatures cited that global environmental changes [13] and events [9] including seasonal variations and physicochemical changes control the dynamics of phytoplankton $[11,12]$.

\section{CONCLUSION}

The following conclusions are hereby formulated based on the findings of this study.

(1) There was a considerable variation in the population of individual species of the two phyla of planktoplankton.

(2) Phytoplankton has multi-directional distribution and dynamic patterns.

(3) The multi-directional distribution and dynamic pattern of the phytoplankton taxa significantly vary from station-tostation.

(4) The physicochemical values are within the acceptable level, hence good water quality.

(5) Surface water temperature, $\mathrm{pH}$, salinity, alkalinity and dissolved oxygen exert insignificant effect on the population of phytoplankton.

\section{ACKNOWLEDGMENT}

The researcher would like to extend her heartfelt gratitude to the management of AMA International UniversityBahrain for the all the support to complete this research; to her field assistants for their full back-ups during the sampling months. 


\title{
International Advanced Research Journal in Science, Engineering and Technology
}

\author{
Vol. 6, Issue 3, March 2019
}

\section{REFERENCES}

[1]. E. Kocum and A. Sulcu, "Analysis of variations in phytoplankton community size structure along the coastal trophic gradient", in Journal of Coastal Research, 2014, vol. 30, issue 4, p777-784, p. 8. (AMAIUBlibresources)

[2]. R.M. Costa, J.B. Matos, K.S.T. Pinto and L.C.C. Percira, "Phytoplankton of a dynamic Amazon sandy beach, Special Issue 65, p1751-1756, p. 6. (AMAIUBlibresources)

[3]. J.B. Matos, A.R.G. Oliveira, W.N. Trendade, N.R. Leite, M.L. Koening, M.L. Pereira and R.H. da Costa, "phytoplankton dynamics in three metropolitan beaches of the Amazon littoral (Sao Lis-Marannao)", in Journal of Coastal Research, 2016, vol. 75, issue sp1, p413-417, p. 5. (AMAIUBlibresources)

[4]. L.Y. Otsuka, F.A.N. Fellosa, M.M.J. Flores and A, Silva, "Dynamics of chlorophyll and oceanographic parameters in the coastal zone: Bara das Jangadas-Permambuco, Brazil", in Journal of Coastal Research, 2016, vol 32, issue 3, p490-499, p.10 (AMAIUBlibresources)

[5]. B.A. Franz, M.J. Behrenfeld, D.A. Siegel, and S.R. Signonni, "Global ocean phytoplankton", Bulletin of the American Meteorological Society, 2016, p587-589, p.3. (AMAIUBlibresources)

[6]. J. Zhao and Y. Yan, "Dynamics of a seasonally forced phytoplankton-zooplankton model with impulsive biological control", Discrete Dynamics in Nature and Society, 2016, p1-, p.9. (AMAIUBlibresources)

[7]. L. Niu, P.H.A. Van Gelder and J.K. Vrijling, "Physical limitation of phytoplankton dynamics in coastal waters," in Journal of Coastal Research, 2017, vol. 33, issues 1, p88-89, p.8.

[8]. C. Spetter, C.A. Popovich, A. Anas, R.O. Asteasnan, R.H. Freije and J.E. Marcovecchio, "Role of nutrients in phytoplankton development during a winter bloom in a eutrophic South American Estuary (Bahia Blanca, Argentina)", in Journal of Coastal Research, 2015, vol. 31, issues 1, p76-87, p.12. (AMAIUBlibresources)

[9]. N. Guelzow, M. Dirks and H. Hillebrand, "Effect of a synchronous light fluctuation on diversity, functional and structural stability of a marine phytoplankton metacommunity", in Oecologia, vol. 176, issue 2, p479-510, p.14. (AMAIUBlibresources)

[10]. J. Huang, J. Gao, G. Hormana and N. Foher, "Modelling effects of environmental variables n short-term spatial changes in phytoplankton biomass in a large shallow lake, Lake Taihu", in Environmental Earth Sciences, 2014, vol. 72, issue 9, p3609-3621, p.13. (AMAIUBlibressources)

[11]. C.H. Ramesh, N. Singh and A. Chauhan, "The influence of physicochemical parameters on phytoplankton distribution in a head water stream of Garhawal Himalayas: A case study,” in Egyptian Journal of Aquatic Research, 2016, vol. 42, issue 1, p11-21.

[12]. W. Yu, "Environmental controls on spatial variability of summer phytoplankton structure and biomass in the Bering Sea," vol. 131 , p1-11.

[13]. C.P. Makinen and T.H. Moisan, "Phytoplankton assemblage patterns in the northern Mid-Atlantic Bight," in Botanica Marina, 2012, vol. 55, issues 5, p445-457, p.13. (AMAIUBlibresources)

[14]. C. Binhzhany, "Pattern of thermal limit of phytoplankton," in Journal of Plankton Research, 2015, vol 37, issue 2, p285-292.

[15]. M.Z. Nassar and S.M. Coharib, "spatial and temporal pattern of phytoplankton composition in Burullus Lagoon, Southern Mediterranean Coast, Egypt," in Egyptian Aquatic Research, 2014, vol. 40, issue 2, p133-142.

[16]. M.M. Ahmed, R.Z. Heneash, M.A. Tadrosa, S.K.M. Hussein, "Potential effect of abiotic factors on the abundance and distribution of phytoplankton in the Western Harbor South Caten Mediterranean Sea, Egypt", in Oceanologia, 2015, vol. 57, Issue 1, p61-70.

[17]. A. Artugal, K. Luffiya and A. Ulgen, "Spatio-temporal patterns of phytoplankton and pigment composition in surface water of south eastern Black Sea," in Oceanologia, 2017, vol. 57, issues 3, p282-299, p.9.

[18]. S.L. Smith, "Phytoplankton size-diversity mediates an emergent trade-off in ecosystem functioning for rare versus frequent disturbances," Scientific Report, vol. 6.

[19]. B.T. Lumeran, "Spatial distribution of marine plankton off the coast of Sitra, Kingdom of Bahrain," in International Journal of Applied and Physical Sciences, 2016, vol. 2, No. 3, p71-78. 